\title{
Coordinated train control in a fully automatic operation system for reducing energy consumption
}

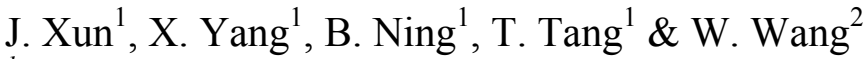 \\ ${ }^{I}$ The State Key Laboratory of Rail Traffic Control and Safety, \\ Beijing Jiaotong University, Beijing \\ ${ }^{2}$ National Engineering Research Center of Rail Transportation Operation \\ and Control System, Beijing Jiaotong University, Beijing
}

\begin{abstract}
Energy efficient train operation includes four levels for energy saving: energy efficient driving, real-time multi-train coordination and rescheduling, energysaving timetabling, and energy-saving planning. For a fully automatic operation system, it provides a flexible way to coordinate trains. The coordination of trains can improve some system performances, such as the efficient use of regenerative energy. The efficient use of energy regenerated by other trains which are during braking phase can contribute to reducing energy consumption. In general, the approaches of coordinated train control for using regenerative energy can be divided into two types: train dwell time control and train running time control. This paper proposes an approach for coordinating trains in fully automatic operation system by modifying running time between adjacent stations. Simulation studies are performed and the usage of regenerative energy and average passenger waiting time is analysed by using the proposed method. It is shown that improvements in the usage of regenerative energy can be achieved by using the proposed method.

Keywords: coordinated train control, energy-saving, fully automatic operation, running time control.
\end{abstract}




\section{Introduction}

Reduction of energy consumption has drawn more and more attractions in railway industry. As a significant way to save energy, energy efficient train operation plays an important role in reducing energy consumption. In reports from RAILENERGY project, it is one of five key technologies to contribute the target of $6 \%$ in energy saving [1]. According to the time scale of train operation, it can be divided into four levels: energy efficient driving, real-time multi-train coordination and rescheduling, energy-saving timetabling, and energy-saving planning. The definition of each level is introduced in Section 2.

Coordinated train control is an energy-saving method in Level 2. It can be used to minimize energy consumption and reduce peak power demand. Researchers proposed many approaches which are based on heuristic method, fuzzy control, direct climbing, genetic algorithm, mixed integer programming, nonlinear programming and rules (in table 1). Among them, some approaches coordinate trains by adjusting train dwell time. This type of coordinated train

Table 1: $\quad$ Previous studies on coordinated train control [2-12].

\begin{tabular}{|c|c|c|c|c|c|}
\hline & Objective & Control & $\begin{array}{l}\text { Power } \\
\text { supply } \\
\text { system }\end{array}$ & $\begin{array}{l}\text { Model/ } \\
\text { algorithm }\end{array}$ & $\begin{array}{c}\text { Regenerative } \\
\text { energy }\end{array}$ \\
\hline $\begin{array}{l}\text { Gordon } \\
\text { and } \\
\text { Lehrer [3] }\end{array}$ & $\begin{array}{c}\text { Min. energy } \\
\text { consumption and peak } \\
\text { power demand } \\
\text { reduction }\end{array}$ & Dwell time & $\mathrm{DC}$ & Heuristics & $\mathrm{Y}$ \\
\hline $\begin{array}{c}\text { Chang } \\
\text { et al. }[4]\end{array}$ & $\begin{array}{l}\text { Min. energy } \\
\text { consumption }\end{array}$ & Dwell time & $\mathrm{DC}$ & Fuzzy control & $\mathrm{Y}$ \\
\hline $\begin{array}{c}\text { Firpo and } \\
\text { Savio [5] }\end{array}$ & $\begin{array}{l}\text { Min. energy } \\
\text { consumption }\end{array}$ & Dwell time & $\mathrm{AC}$ & $\begin{array}{c}\text { Direct climbing } \\
\text { method }\end{array}$ & $\mathrm{Y}$ \\
\hline $\begin{array}{c}\text { Guo } \\
\text { et al. }[6]\end{array}$ & $\begin{array}{l}\text { Min. energy } \\
\text { consumption }\end{array}$ & Dwell time & $\mathrm{DC}$ & Heuristic & $\mathrm{Y}$ \\
\hline $\begin{array}{l}\text { Sanso and } \\
\text { Girard [7] }\end{array}$ & $\begin{array}{l}\text { Peak power demand } \\
\text { reduction }\end{array}$ & Dwell time & $\mathrm{DC}$ & Heuristic & $\mathrm{N}$ \\
\hline $\begin{array}{c}\text { Albrecht } \\
{[2]}\end{array}$ & $\begin{array}{c}\text { Min. energy } \\
\text { consumption and peak } \\
\text { power demand } \\
\text { reduction }\end{array}$ & $\begin{array}{l}\text { Running } \\
\text { time }\end{array}$ & $\mathrm{DC}$ & $\begin{array}{l}\text { Genetic } \\
\text { algorithm }\end{array}$ & $\mathrm{Y}$ \\
\hline $\begin{array}{c}\text { Chen } \\
\text { et al. }[8]\end{array}$ & $\begin{array}{l}\text { Peak power demand } \\
\text { reduction }\end{array}$ & Dwell time & $\mathrm{DC}$ & $\begin{array}{c}\text { Genetic } \\
\text { algorithm }\end{array}$ & $\mathrm{Y}$ \\
\hline $\begin{array}{l}\text { Kim } \\
\text { et al. [9] }\end{array}$ & $\begin{array}{c}\text { Min. energy } \\
\text { consumption and peak } \\
\text { power demand } \\
\text { reduction }\end{array}$ & Dwell time & $\mathrm{DC}$ & $\begin{array}{l}\text { Mixed integer } \\
\text { programming }\end{array}$ & $\mathrm{Y}$ \\
\hline $\begin{array}{c}\mathbf{G u} \\
\text { et al. }[10]\end{array}$ & $\begin{array}{l}\text { Peak power demand } \\
\text { reduction }\end{array}$ & $\begin{array}{c}\text { Running } \\
\text { time }\end{array}$ & $\mathrm{DC}$ & $\begin{array}{c}\text { Nonlinear } \\
\text { programming }\end{array}$ & $\mathrm{N}$ \\
\hline $\begin{array}{c}\text { Takeuchi } \\
\text { et al. } \\
{[11,12]}\end{array}$ & $\begin{array}{l}\text { Peak power demand } \\
\text { reduction }\end{array}$ & $\begin{array}{l}\text { Running } \\
\text { time }\end{array}$ & $\mathrm{DC}$ & Rule-based & $\mathrm{N}$ \\
\hline
\end{tabular}


control suffers from mainly two points [2]. In FAO system, the responsibility for the clearance of the train is taken by system, however, precise time keeping in the order of seconds also can't be guaranteed during rush hour. Moreover, running time control method can use time reserve for longer coasting to save energy. So we choose running time control method in our research.

In previous researches on running time control method, they analyzed the variation of energy consumption, 15-min-average power and regenerative rate. However its impact to train headways and passenger throughout was not discussed. So in this paper, we propose an analytical method to adjust train running time in real-time and analyze its impact to headways and passenger throughout.

In next section, four levels in energy efficient train operation are introduced. In section 3 , by modifying train running time, multiple trains are coordinated to optimize the utility of regenerative energy. An analytical method is applied to solve this problem. In section 4 , a case study is carried out for a Chinese DC electric urban rail transit system.

\section{Levels for energy-saving}

Railway transportation system can be operated at different levels of energysaving defined below. The definition for each level of energy-saving arises from its time scale for operating. The characters for a given energy-saving level are also defined in the following sub-clauses and table 2 . We can compare and find the differences between any two levels from table 2 .

\section{- Level 1: Energy-efficient driving}

In this level of energy-saving, the process of a train running through a section between stations is optimized. A skilled driver or ATO will drive a train in a section between stations by following an optimal speed profile. The optimal speed profile is generated in real-time to achieve the lowest energy consumption while fulfilling given timetable constraints.

\section{- Level 2: Real-time multi-train coordination and rescheduling}

In this level of energy-saving, the process of multiple trains accelerating, decelerating and passing a bottleneck section is optimized. Every train has an upto-date, conflict free schedule containing time, speed and route information. These schedules must have an accuracy of seconds. The timing and order for each train passing bottleneck section will be rescheduled in real-time. These can improve the usage of regenerative energy and avoid unnecessary braking, thus minimize energy consumption.

\section{- Level 3: Energy-saving timetabling}

In this level of energy-saving, the daily/month plan of multiple trains travelling in a railway network is optimized. An energy-saving daily/month timetable will be generated which includes the arrival and departure times of trains at stations and other relevant locations such as junctions. It will also provide a buffer time (called recovery time in Britain) to cater for variability in driving style and other factors, such as dwell times and adhesion problems. The basic idea of energy- 
saving timetabling is the optimal synchronization to maximum usage of regenerative energy. Generally, the off-line computation at this level is acceptable. It needs to consider annual/seasonal transport plan, train connection, substation deployment and so on.

\section{- Level 4: Energy-saving planning}

In this level of energy-saving, the seasonal/annual plan of multiple trains travelling in a railway network is optimized. An optimal transport plan is drawn up to meet the traffic demand. During the optimization, the operation cost is minimized by consider the bill pattern. Different bill patterns influence our choice on how to use regenerative energy.

Except for saving energy, different levels for energy-saving can benefit different aspects of railway system. We summarize the benefits for each level in table 3. From table 3, we can see that reducing energy consumption and peak

Table 2: $\quad$ Levels for energy-saving.

\begin{tabular}{|c|c|c|c|c|}
\hline & Level 1 & Level 2 & Level 3 & Level 4 \\
\hline $\begin{array}{c}\text { Time scale of } \\
\text { operating }\end{array}$ & Minute & Minute/Hour & Hour/Daily & Month/Year \\
\hline $\begin{array}{c}\text { Space scale of } \\
\text { operating }\end{array}$ & $\begin{array}{l}\text { Sections } \\
\text { between } \\
\text { stations }\end{array}$ & $\begin{array}{c}\text { Junction } \\
\text { area/bottleneck }\end{array}$ & Line/Network & $\begin{array}{l}\text { The whole } \\
\text { network }\end{array}$ \\
\hline $\begin{array}{l}\text { Number of } \\
\text { trains }\end{array}$ & Single train & $\begin{array}{c}\text { A couple/ } \\
\text { bunch of trains }\end{array}$ & $\begin{array}{l}\text { A bunch of } \\
\text { trains }\end{array}$ & $\begin{array}{l}\text { A bunch of } \\
\text { trains }\end{array}$ \\
\hline $\begin{array}{c}\text { Algorithm } \\
\text { computation } \\
\text { speed }\end{array}$ & High & High & Medium & $\begin{array}{l}\text { As high as } \\
\text { possible }\end{array}$ \\
\hline $\begin{array}{c}\text { Control } \\
\text { accuracy }\end{array}$ & seconds & seconds & - & - \\
\hline Output & $\begin{array}{l}\text { Optimal speed } \\
\text { profile }\end{array}$ & $\begin{array}{l}\text { Optimal } \\
\text { schedule }\end{array}$ & $\begin{array}{c}\text { Optimal } \\
\text { timetable }\end{array}$ & $\begin{array}{c}\text { Optimal } \\
\text { transport plan }\end{array}$ \\
\hline Consideration & $\begin{array}{c}\text { Timetable; } \\
\text { Train } \\
\text { characteristics; } \\
\text { Running time; } \\
\text { Line } \\
\text { condition; } \\
\text { Infrastructure; } \\
\text { Gradients; }\end{array}$ & $\begin{array}{c}\text { Timetable; } \\
\text { Train } \\
\text { characteristics; } \\
\text { Running time; } \\
\text { Signaling } \\
\text { system; } \\
\text { Substation } \\
\text { deployment; } \\
\text { Dwell time; } \\
\text { Conflict } \\
\text { detection and } \\
\text { resolution; }\end{array}$ & $\begin{array}{l}\text { Transport plan; } \\
\text { Infrastructure; } \\
\text { Rolling stock } \\
\text { configuration; } \\
\text { Signaling } \\
\text { design; } \\
\text { Dwell time; } \\
\text { Connection } \\
\text { with other } \\
\text { lines; } \\
\text { Substations } \\
\text { deployment; } \\
\text { Minimization } \\
\text { of conflicts; }\end{array}$ & $\begin{array}{l}\text { User demand } \\
\text { pattern; } \\
\text { Bill pattern; } \\
\text { Trade-off } \\
\text { between travel } \\
\text { time and energy } \\
\text { consumption; } \\
\text { Minimization of } \\
\text { conflicts; } \\
\text { Train fleet; }\end{array}$ \\
\hline
\end{tabular}


power can be achieved in every level. The energy-saving effect of methods in these levels is different, such as how much energy is saved. However, there is no comparable value for these methods on a common basis, because there is no general measurement until now.

Table 3: $\quad$ Advantages of each level for energy-saving.

\begin{tabular}{|c|c|c|c|c|}
\hline \multirow{2}{*}{ Advantages of Energy-saving } & \multicolumn{5}{|c|}{ LEVEL } \\
\cline { 2 - 6 } & $\mathbf{1}$ & $\mathbf{2}$ & $\mathbf{3}$ & $\mathbf{4}$ \\
\hline Reduced energy and power consumption & $\sqrt{ }$ & $\sqrt{ }$ & $\sqrt{ }$ & $\sqrt{ }$ \\
\hline Improved working environment for dispatchers and drivers & $\sqrt{ }$ & $\sqrt{ }$ & $\sqrt{ }$ & $\sqrt{ }$ \\
\hline Reduced wear on vehicles and track & $\sqrt{ }$ & $\sqrt{ }$ & $\sqrt{ }$ & $\sqrt{ }$ \\
\hline Reduced passenger average waiting time & & $\sqrt{ }$ & $\sqrt{ }$ & $\sqrt{ }$ \\
\hline Reduced peak power demand & & $\sqrt{ }$ & $\sqrt{ }$ & $\sqrt{ }$ \\
\hline More efficient train dispatching & & $\sqrt{ }$ & $\sqrt{ }$ & $\sqrt{ }$ \\
\hline Improved line capacity & & $\sqrt{ }$ & $\sqrt{ }$ & $\sqrt{ }$ \\
\hline Improved solving of disrupted traffic situations & & $\sqrt{ }$ & & \\
\hline Better utilization of rolling stock and train staff & & & $\sqrt{ }$ & $\sqrt{ }$ \\
\hline Conflict resolution and minimization of conflicts & & $\sqrt{ }$ & $\sqrt{ }$ & $\sqrt{ }$ \\
\hline
\end{tabular}

\section{Coordinated train control by adjusting running time}

As an energy-saving method in level 2, the proposed method is an approach to coordinate the beginning time of traction phase of preceding train and braking phase of following train by adjusting running time of the following train.

As shown in fig. 1, train $i$ is on the way to station $n$ and train $i+1$ stops at station $n+1$. The running time $\mathrm{T}_{\mathrm{rm}}(i)$ of train $i$ on section $m$ is predictable. And according to the timetable, the dwell time $\operatorname{Td}_{n}$ of train $i$ at station $n$ is determinate. In urban transit system, trains usually accelerate with maximum acceleration rate during traction phase. So the power profiles during traction phase of all trains have the same style at different sections. From fig. 1, we can see that modification of the following train's braking profile can change the overlapping region between two successive trains in Power-Time diagram. This overlapping region means the amount of regenerative energy that can be used. Then we can obtain a regenerative energy usage function:

$$
\mathrm{F}=\int_{\mathrm{t}_{1}}^{\mathrm{t}_{2}} \min \left(\mathrm{E}_{\text {regeneration }}(\mathrm{i}+1), \mathrm{E}_{\text {traction }}(\mathrm{i})\right) \mathrm{dt}
$$




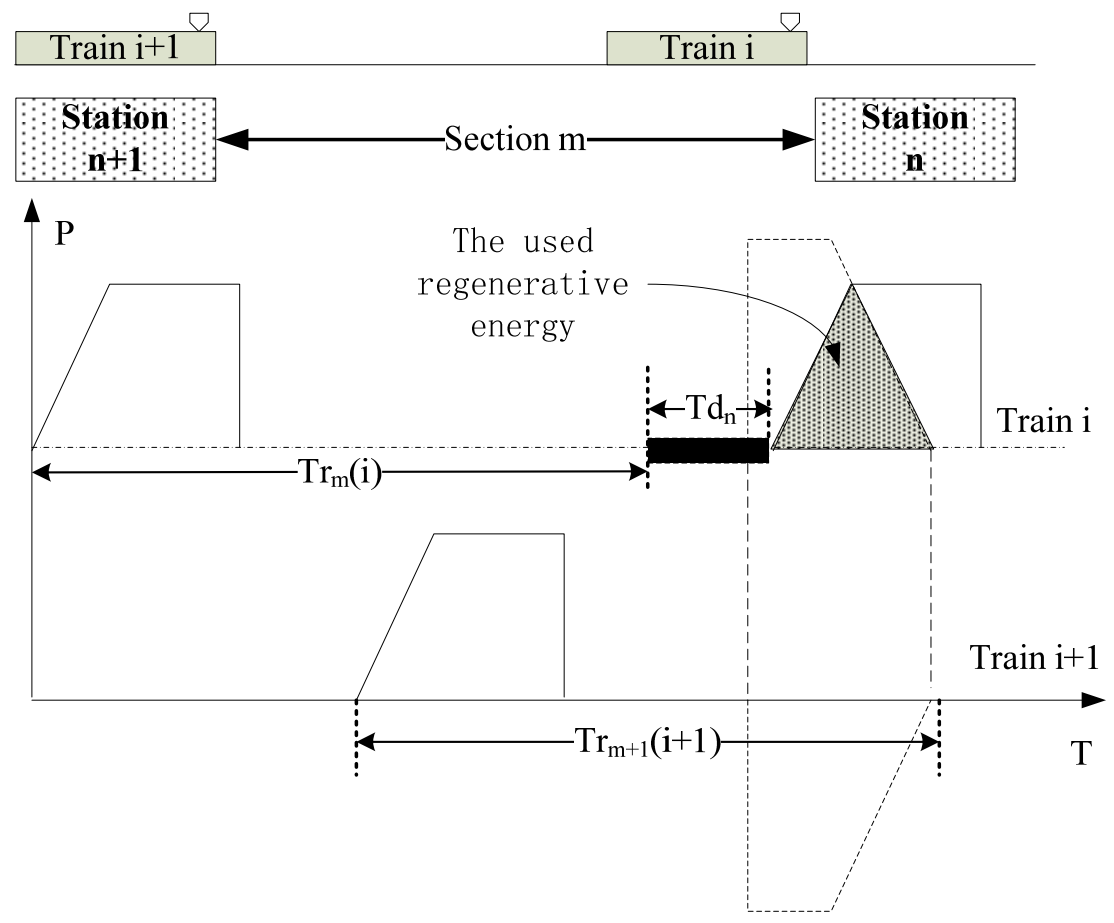

Figure 1: $\quad$ Problem description.

We can obtain the optimized value of the function by adjusting the beginning time of following train's braking properly, thereby improving the usage of regenerative energy between two successive trains.

The configuration of the coordinated train control method is shown in fig. 2 . Whenever a train stops at a station, the coordinated train control method is applied to determine the best braking time on the basis of the optimal running time to the next station. The generation of optimal running time considers predicted departure time of preceding trains at next station and train operational characteristics, including acceleration and deceleration rates, the maximum attainable speed and so on. The proposed method could serve as a major component in the operational control system at stations.

In FAO system, the proposed method can interact with other subsystems (e.g., train control, passenger monitor) to collect data, including train positions, speeds, delays and passenger demands at stations, while the speed profile for each train generated on the basis of its optimal running time to the next station is generated to guide train operations.

The effect of the proposed method is sensitive to the precision of train's departure time prediction. If the deviation of predicted train running time is too large, the difficulty of coordinated train control increases. 


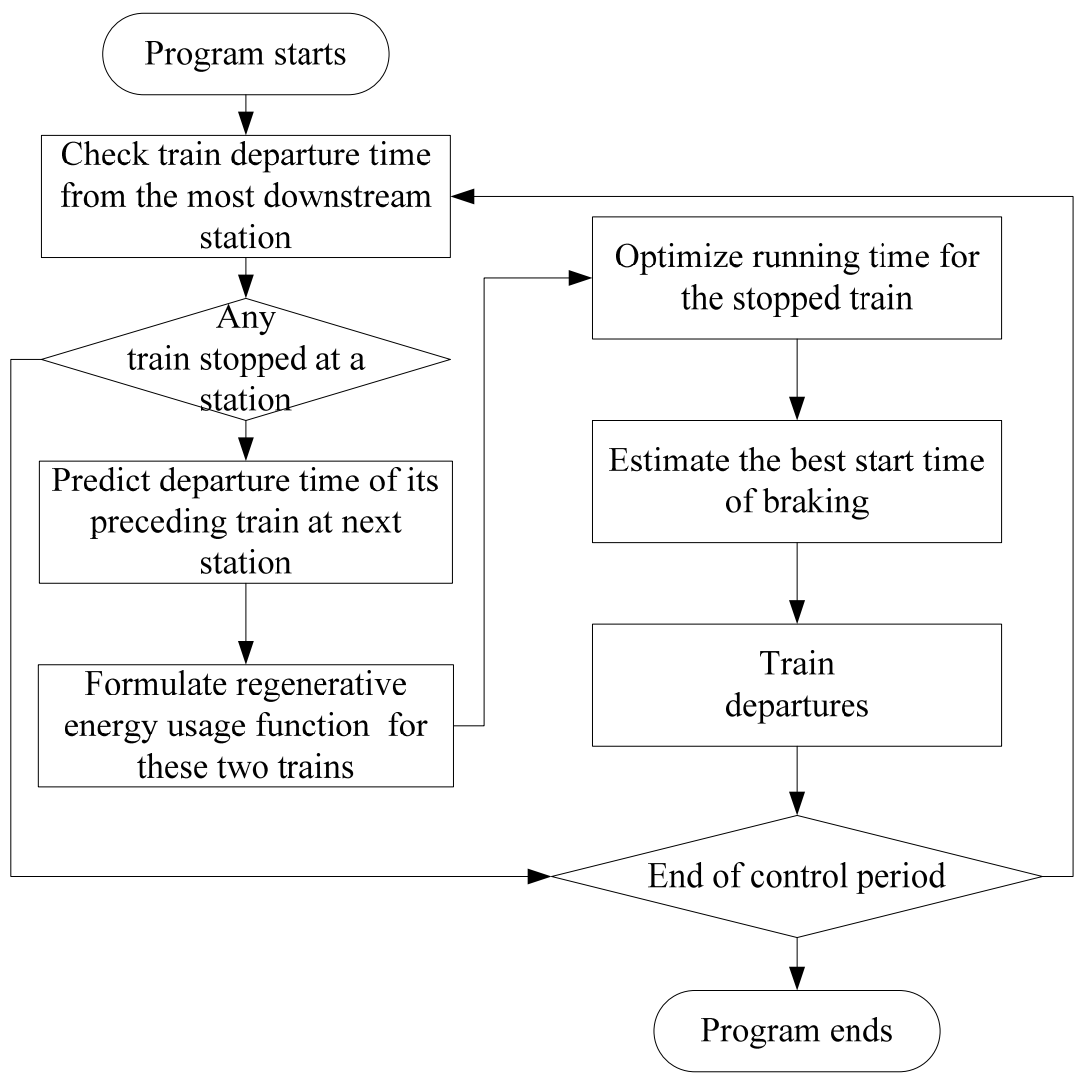

Figure 2: Configuration of the proposed method.

If the station and its next station do not belong to the same substation, the proposed method can't be applied at this station. Because the regenerative energy generated by the following train can't be used by the preceding train.

\section{Discussion}

A simulation has been carried out for one line of the Beijing Metro network: Yizhuang line, which is 23.23 kilometers long. As shown in fig. 3, the subway has 14 stations, running from Songjiazhuang Station (transfer to Line 5, Beijing Metro) to Yizhuang Railway Station (transfer to Jing-Jin intercity high-speed railway line). There are 6 substations along Yizhuang line. The number of stations for which a substation provides power is decided by the distance between stations. Generally speaking, the power supply area for each substation is 5 kilometers approximately (3-4 stations).

The values of parameters used in simulation are listed in table 4 . These parameters are predefined in simulation. The dwell time at every station is 


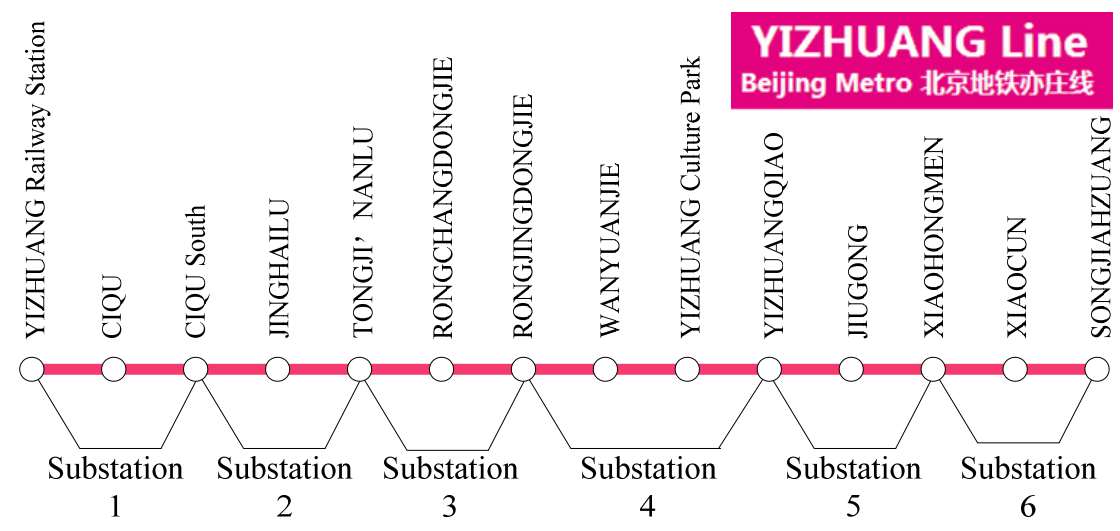

Figure 3: $\quad$ Graph of Yizhuang line (provided by the Beijing Metro).

Table 4: $\quad$ Values of some parameters.

\begin{tabular}{|c|c|c|}
\hline Parameters & Value & Unit \\
\hline Number of trains in simulation & 10 & - \\
\hline Mass of train & 287000 & $\mathrm{Kg}$ \\
\hline Maximum speed of train & 72 & $\mathrm{Km} / \mathrm{h}$ \\
\hline Maximum acceleration rate of train & 0.8 & $\mathrm{~m} / \mathrm{s}^{2}$ \\
\hline Deceleration rate caused by resistance & 0.02 & $\mathrm{~m} / \mathrm{s}^{2}$ \\
\hline Maximum deceleration of train & 1 & $\mathrm{~m} / \mathrm{s}^{2}$ \\
\hline Dispatch headway at original station & 120 & $\mathrm{~s}$ \\
\hline Station length & 180 & $\mathrm{~m}$ \\
\hline Train length & 180 & $\mathrm{~m}$ \\
\hline
\end{tabular}

obtained from timetable published by Beijing Metro. The first train in simulation uses the speed profile recorded during real operation in Yizhuang line to guide driving style.

The comparison of applying the proposed method is shown in fig. 4, which illustrates the curves of used regenerative energy for each train. The solid line denotes the values using the proposed method, and the dotted line denotes the values using the basic method where each train uses the same typical speed profile of train 1. We can see that the usage of regenerative energy is improved in fig. 4. Because the following train provides regenerative energy for preceding train, so the used regenerative energy of Train 10 is zero. The average used regenerative energy is $3.4 \mathrm{kWh}$ per train by using the basic method and $39.5 \mathrm{kWh}$ per train by using the proposed method. The utility of regenerative energy is increased by more than 11 times. In real operation, the record of used energy for one train runs one trip in Yizhuang line is about $400 \mathrm{kWh}$, so it saves 9.88\% approximately on energy consumption. 


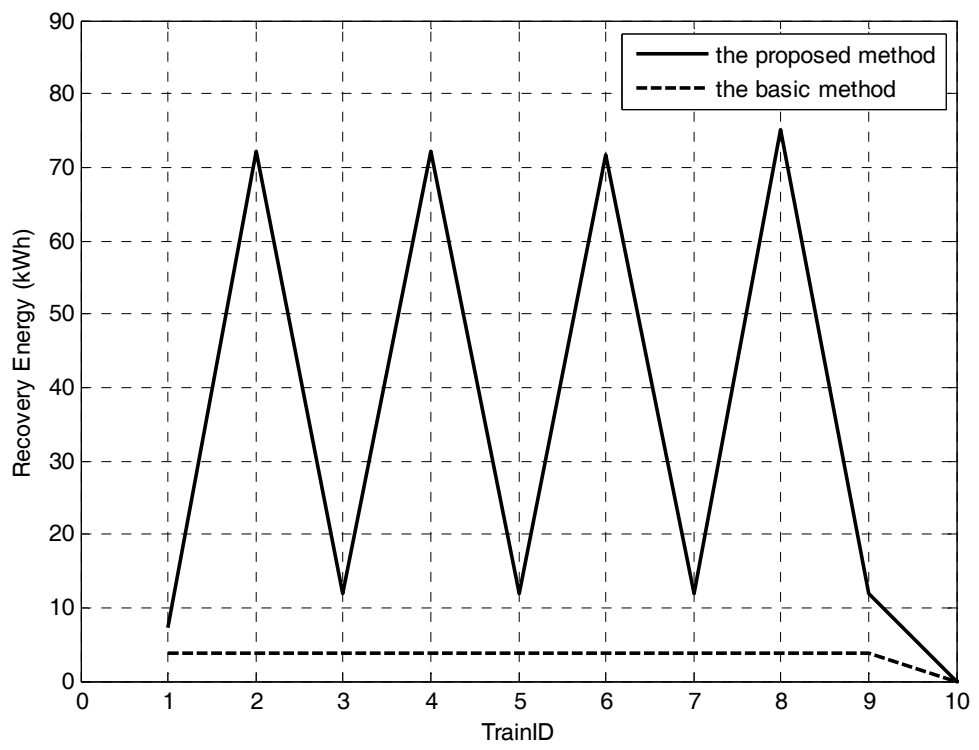

Figure 4: The usage of regenerative energy.

In Ref. [13], a model to estimate average passenger waiting time for a transit route while considering stochastic (random) vehicle and passenger arrivals at stations is introduced:

$$
\mathrm{E}(\mathrm{W})=\mathrm{E}(\mathrm{h}) / 2+\sigma^{2}(\mathrm{~h}) / 2 \mathrm{E}(\mathrm{h})
$$

Based on eqn. (2), we count the average arrival headway at each station and compute average passenger waiting time. The simulation result is shown in Fig. 5. Although the average arrival headway at each station is the same, shown in fig. 5(a), the average passenger waiting time at downstream stations increases

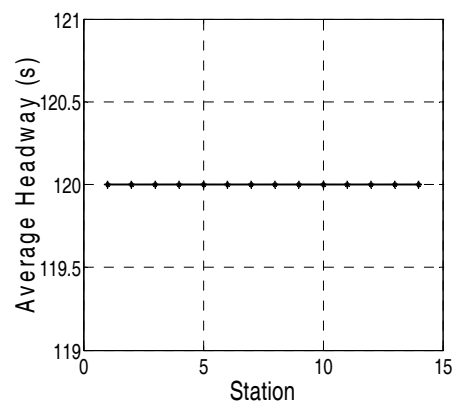

(a)

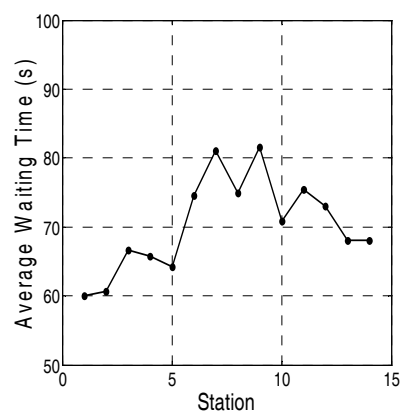

(b)

Figure 5: Average headway and passenger waiting time at each station. 
firstly, because the running time is changed and the variance of headway is increased. When it reaches a peak, it drops progressively. The highest average waiting time is $80 \mathrm{~s}$ and the lowest is $60 \mathrm{~s}$.

There is only a 20 s increase after using the proposed method. The proposed method considers the impact to the arrival headway caused by running time modification. It not only uses the regenerative energy as much as possible but also limits the running time to decline its impact to average passenger waiting time.

\section{Conclusion}

In this paper we introduced four levels for energy-saving in energy efficient train operation firstly. Then we proposed an analytical method of coordinated train control for energy saving, which is in level 2: real-time multi-train coordination and rescheduling.

Before departing from a station, each train will optimize its running time in the next inter-station section based on the prediction of the preceding train's departure time at next station. There is a trade-off between energy saving and average passenger waiting time reduction. By using the proposed method, the adjustment of train running time between stations can improve regenerative energy usage with minor disturbance on average passenger waiting time.

Until now the proposed method only computes the usage of regenerative energy based on the transfer of trains' kinetic energy. We need a detailed model to describe the process of the generation and usage of regenerative energy precisely where transmission loss and converter efficiency will be also considered.

\section{Acknowledgements}

This research is partly supported by the High Technology Research and Development Program of China ('863' Program, No. 2011AA110502), the State Key Laboratory of Rail Traffic Control and Safety (No. RCS2010ZZ003, No. RCS2011ZZ007) and Beijing Jiaotong University (No. 2011JBZ014, No. 2011JBM163)

\section{References}

[1] Railenergy, www.railenergy.org

[2] T. Albrecht, Reducing power peaks and energy consumption in rail transit systems by simultaneous train running time control, Computers in Railways IX, WIT Press, pp. 885-894, 2004.

[3] Gordon, S.P. and Lehrer, D.G., Coordinated train control and energy management control strategies, Proceedings of the 1998 ASME/IEEE Joint in Railroad Conference, pp. 165-176, 1998. 
[4] Chang, C.S., Phoa, Y.H., Wang, W. and Thia, B.S., Economy/regularity fuzzy-logic control of DC railway systems using event-driven approach, IEE Proceedings on Electric Power Applications, 143(1), pp. 9-17, 1996.

[5] Firpo, P. and Savio, S., Optimized train running curve for electrical energy saving in autotransformer supplied AC railway systems, Proc. of the IEE Conference on Electric Railways in a United Europe, pp. 23-27, 1995.

[6] Guo, H.-J., Ohashi, H. and Ishinokura, O., DC electric train traffic scheduling method considering energy saving - Combination of train traffic parameters for larger regenerative power (in Japanese), Transactions of the Institute of Electrical Engineers of Japan, 119-D(11), pp. 1337-1344, 1999.

[7] Sanso B. and Girard, P., Train scheduling desynchronization and power peak optimization in a subway system, Proceedings of the 1995 IEEE/ASME Joint in Railroad Conference, pp. 75-78, 1995.

[8] Chen, J.F., Lin, R.L. and Liu, Y.C., Optimization of an MRT Train Schedule: Reducing Maximum Traction Power by Using Genetic Algorithms, IEEE Transactions on Power Systems, 20(3), pp. 1366-1372, 2005.

[9] Kim, K.M., Kim, K.T. and Han, M.S., A model and approach for synchronized energy saving in timetabling, the 9th world congress on railway research, Lille, 2011.

[10] Gu, Q., Cao, F. and Tang, T., novel peak power demand reduction strategy under a moving block signalling system, Computers in Railways XII, WIT Press, pp.663-674, 2010.

[11] Takeuchi, H. and Goodman, C. J., A simulation study of peak demand reduction strategies when starting under moving block signalling, Computers in Railways V, WIT Press, pp. 187-196, 1996.

[12] Takeuchi, H., Goodman, C. J. and Sone, S., Peak demand reduction techniques when starting under moving block signalling, International Conference on Developments in Mass Transit Systems, pp. 280-285, 1998.

[13] Ding Y. and Chien, S. I., Improving transit service quality and headway regularity with real-time control, Transportation Research Record, 1760, pp. 161-170, 2001. 